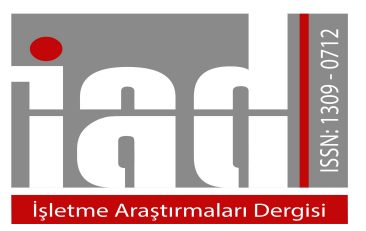

İşletme Araştırmaları Dergisi

Journal of Business Research-Turk

10/3 (2018) 974-994

Journal Of

Business Research

Turk

www.isarder.org

\title{
Algılanan Kontrolün Psikolojik Sahiplenmeye Etkisinde Maksimum Fiyatı Ödeme İstekliliğinin Düzenleyici Rolü: Mercedes Marka Otomobil Kullanıcıları Üzerinde Bir Araştırma
}

\author{
Moderating Role of Willingness to Pay More in the Effect of Perceived \\ Control on Psychological Ownership: A Study on Mercedes Brand \\ Automobile Owners
}

\author{
Selma KALYONCUOĞLU \\ Ankara Hacı Bayram Veli Üniversitesi \\ İktisadi ve İdari Bilimler Fakültesi \\ İşletme Bölümü \\ Ankara, Türkiye \\ orcid.org/0000-0003-4745-7836 \\ selmakalyoncuoglu@gmail.com
}

\section{Özet}

Algılanan kontrol, psikolojik sahipliği oluşturan etkenlerden bir tanesidir. Bu etki içerisinde ilişkiyi farklılaştırıp ilişkinin yönünü ve/veya gücünü değiştiren bir değişken olarak maksimum fiyatı ödeme istekliliğinin etkisi de araştırma modeline dâhil edilmiştir. Bu kapsamda çalışma ile tüketici davranışı bağlamında algılanan kontrol ve psikolojik sahiplik ilişkisinde maksimum fiyatı ödeme istekliliğinin düzeleyici etkisi anlaşılmaya çalışılmıştır. Mercedes marka otomobil kullanıcıları üzerinde yapılan bir araştırma ile 402 adet tüketicinin tutumları ölçülmeye çalışılmıştır. Araştırma sonucunda, algılanan kontrolün kullanıcıların Mercedes marka otomobillerine yönelik psikolojik sahipliklerini olumlu yönde etkilediği ve bu etkide maksimum fiyatı ödeme istekliliğinin düzenleyici rolü olduğu tespitine ulaşılmıştır. Maksimum fiyatı ödeme istekliliğinin yüksek olduğu kullanıcılar için algıladıkları kontrol ile psikolojik sahiplik arasındaki ilişkinin arttığı görülürken; maksimum fiyatı ödeme istekliliğinin düşük olduğu kullanıcılarda ise bu ilișkinin çok fazla etkilenmediği ortaya konulmuştur. Dolayısıyla bireylerin algıladıkları kontrol ile psikolojik sahiplikleri arasındaki ilişkinin, maksimum fiyatı ödeme istekliliği yüksek olan kullanıcılarda, düşük olanlardan daha kuvvetli olduğu sonucuna ulaşılmaktadır.

Anahtar Kelimeler: Algılanan Kontrol, Psikolojik Sahiplenme, Maksimum Fiyatı Ödeme İstekliliği, Düzenleyici Etki

\section{Abstract}

Perceived control is one of the elements of psychological ownership. The effect of willingness to pay more which is a variable changing and differentiating the direction and/or strength of the relation between the two has been included in the research model. In this regards, this study aimed to investigate moderating effect of willingness 
to pay more in the relation between perceived control and psychological ownership within the framework of consumer behaviour. This study was carried out with Mercedes brand automobile owners and a total of 402 consumers' attitudes were measured. The results of the study showed that perceived control had a positive effect on psychological ownership level of Mercedes brand automobile owners and willingness to pay more had a moderating role in this effect. It was revealed that the relation between perceived control and psychological ownership increased for individuals who were more willing to pay more; on the other hand, this relation was not affected much for individuals who were less willing to pay more. Therefore, it has been concluded that the relation between individuals' perceived control and psychological ownership was stronger in individuals who were more willing to pay more compared to individuals who were less willing to pay more.

Keywords: Perceived Control, Psychological Ownership, Willingness to Pay More, Moderating Effect

\section{Giriş}

Bireylerin bir nesneye ilişkin yasal sahiplikleri olmasa bile, maddi ya da maddi olmayan ilgili nesneye yönelik bireylerde gelişen psikolojik anlamda güçlü bağlanma hissi, akademik alan yazında psikolojik sahiplenme olarak ilk defa Pierce, Kostova ve Dirks (2001) tarafından ortaya konulmuştur. İnsanlık tarihi boyunca insanoğlunun çeşitli nesnelere sahipliği mevcut olmuş ve bu da toplumların temelini oluşturmuştur. Sahipliğin yasal boyutundan öte psikolojik boyutunun ele alınması, bireylere ilgili nesneye ilişkin sağlanan yasal haklardan ziyade ilgili nesneyi bireylerin kendininmiş gibi hissetmesini ve algılamasını sağlamaktadır. Dolayısıyla yasal sahiplikte bile oluşamayan "kendininmiş gibi sahiplenme duygusu" psikolojik sahiplenmede ortaya çıkmaktadır. Dolayısıyla bireylerin tutumları ve davranışları üzerinde etkili olabileceği gözlemlenen bu kavram, özellikle örgüt çalışanları üzerinden araştırılmaya başlanmıştır (Dyne ve Pierce, 2004; Mayhew ve Diğ., 2007; Liu ve Diğ., 2012). Zaman içerisinde tüketici davranışı bağlamında, psikolojik sahiplenme kavramı pazarlama yazını tarafindan da ele alınmaya başlanmıştır (Hulland, Thompson ve Smith, 2015; Jussila ve Diğ., 2015; Karahanna, Xu ve Zhang, 2015; Zhao, Chen and Wang, 2016; Alkaya ve Devrani, 2018). Bu çalışma kapsamında da araştırmacı tarafından bizzat odak grup çalışmasıyla gözlemlenen tüketicilerin Mercedes markasına yönelik geliştirdiği psikolojik bağlilık incelenmektedir.

$\mathrm{Bu}$ çalışmanın amacı, Mercedes kullanıcılarının algıladı̆̆ı kontrolün markaya yönelik geliştirdikleri psikolojik sahipliğe etkisini ve bu etkide maksimum fiyatı ödeme istekliliğinin düzenleyici rolünü ortaya koymaktır. Hâlihazırda kullandıkları markaya ilişkin yasal sahipliği olan tüketicilerin, markayı psikolojik sahiplenmelerinde algıladıkları kontrolün rolünün ve bu etkide ilgili ürüne daha yüksek düzeyde ödeme yapma istekliliklerinin düzenleyici etkisinin araştırılması çalışmanın pazarlama yazınına yaptığı önemli bir katkıdır.

Çalışma, üç temel bölümden oluşmaktadır. İlk bölümde, araştırmaya konu olan kavramlar tanıtılmıştır. İkinci bölümde, algılanan kontrolün psikolik sahiplenme üzerindeki etkisi ve bu etkide maksimum fiyatı ödeme istekliliğinin düzenleyici rolünün tespitine yönelik hipotezler için analizler yapılmış ve elde edilen bulgular ortaya konulmuştur. Son bölümde ise çalışmanın sonuçlarına ve tartışmaya yer verilerek gelecek çalışmalar için önerilerde bulunulmuştur. 


\section{Kavramsal Çerçeve}

Tüketici davranışı perspektifinde bireylerin algıladıkları kontrolün psikolojik sahiplenmeleri üzerideki etkisine ve bu etkinin kimler için (maksimum fiyatı ödeme istekliliği yüksek olanlar/düşük olanlar) daha kuvvetli olduğu sorusuna cevap aramak üzere bu ampirik çalışma tasarlanmıştır. Alanyazından hareket edilerek araştırma modeli ortaya konulmuş ve hipotezler oluşturulmuştur. Bu bölümde araştırma modeline dâhil olan söz konusu değişkenler, kavramsal olarak açıklanmaktadır.

\subsection{Algilanan Kontrol}

Psikolojik sahiplenme olgusunu oluşturan temel niteliklerden biri olan algılanan kontrol, kişinin bir objeyi kontrolü olarak ifade edilmektedir. Rudmin ve Berry (1987) de yaptıkları çalışmada sahipliğin temel olarak nesneleri kullanma ve kontrol etme yeteneği anlamına geldiği tespitine ulaşmışlardır (Pierce, Kostova ve Dirks, 2001, s. 301). Sahipliklerin, bireyin kimliğini şekillendirdiği anlayışını taşıyan McClelland (1951) da, bireylerin dış nesneleri kontrol edebilmelerinin onların genişletilmiş benliklerinin (kişinin sahip olduğu varlıklar üzerinden kişilik ve kimliğini oluşturması) bir parçasını oluşturduğunu iddia etmiştir. Öte yandan, nesneler üzerindeki kontrol eksikliğinin de ilgili nesnenin bireyin benliğinin bir parçasını oluşturamayacağ sonucunu doğurduğu ifade edilmiştir (Mayhew ve Diğ., 2007, s. 482). Dolayisiyla bireyin kendini algılaması ve yorumlaması, kişilik ve kimliğini oluşturması sahip olduğu nesneler üzerinden şekillenmektedir (Belk, 1988, s. 140). Bireye, nesneler üzerinde kontrol imkânı sağlanarak kendi etkisini ortaya çıkarmasına imkân sunulması da bireyin ilgili nesne üzerindeki sahiplik duygusunun gelişimini oluşturmaktadır.

Bireylerin, kimlikleri ve kişilikleri için önemli olan nesnelere yönelik bağl1lık geliştirmeleri olasıdır. Kimliğin parçası olan nesnelerin, kişinin kimliği ile daha az ilişsili olan nesnelerden daha fazla duygusal bağlılık yarattığı da ifade edilebilmektedir. Dolayısıyla duygusal bağlılığın tanımlanmasında; sahipliğin benlikle ilişkili olan yönlerini, fonksiyonel bağl1lıktan kaynaklanan ve benlikle ilişkili olmayan yönlerden ayırmanın gerekliliğine vurgu yapmaktadır (Belk, 1989, s. 130).

Pazarlama yazını bağlamında değerlendirildiğinde; Fuchs, Prandelli ve Schreier (2010)'in çalışması, ürünlerin seçim sürecine katılarak karar verme yetkisine sahip olan tüketicilerin psikolojik olarak daha güçlü bir sahiplik duygusu geliştirdiğini göstermektedir. Dolayısıyla, tüketicilerinin tercihlerini yansıtan ve süreci kontrol etmelerine imkân sağlayan yapının psikolojik sahiplik üzerindeki etkisi deneysel bir çalışmayla ortaya konmuştur. Öte yandan Agarwal ve Ramaswami (1994)'nin çalışması da işletmenin çalışanlarının karar verme sürecine aktif olarak katılmaları ve sonuçları etkileyebilmeleri durumunda nihai kararların "bireylerin kararları" haline geldiğini ortaya koymaktadır ve sonuçlardan kısmen sorumlu olmanın da olumlu duygular ortaya çıkarma eğilimi oluşturduğu söylenebilmektedir (Fuchs, Prandelli ve Schreier, 2010, s. 67).

\subsection{Psikolojik Sahiplenme}

İnsanlık tarihinin başından beri insanlar mülk, arazi, eşya ve ilişki gibi pek çok şeye sahip olmuşlardır ve bu tür sahiplenme de günümüzde birçok çağdaş toplumun temelini oluşturmaktadır. İnsanlar sahiplenme hedeflerine karşı özel duygular beslemekte ve sahip oldukları nesneler/eşyalar için geliştirdikleri ilişkilerine yönelik güçlü bir tutum sergilemektedirler. Nesnelere/eşyalara karşı gösterilen bu sahiplenme duyguları doğası gereği hayli psikolojik bir özelliğe sahiptir. Sahip olunan nesneye gösterilen bu psikolojik (duygusal veya bilişsel) bağ Pierce, Kostova ve Dirks (2001, 
2003) tarafından psikolojik sahiplenme (PS) olarak adlandırılan olgunun özünü oluşturmaktadır. Dolayısıyla da sahiplenmenin psikolojik yönü sıklıkla nesneyle kurulan sürekli ilişkinin altında yatan temel sebep haline gelmiştir (Asatryan ve Oh, 2008, s. 363).

Pierce, Kostova ve Dirks (2001, 2003), pskilojik sahiplenme teorisini, bir hedefe/nesneye (maddi ya da maddi olmayan) ya da bu hedefin/nesnenin bir parçasına (ör. "Benimdir") sahip olma ve psikolojik olarak bağlı olma hissini alan yazına önererek; kavramın teorik çerçevesinin çizilmesine önemli katkı sağlamıştır. Öyle ki Pierce, Kostova ve Dirks (2001, 2003); "psikolojik sahiplenme” kavramını, örgüt içinde çalışan bireylerin yasal sahiplikten ayrı olarak şekillendirdikleri ve örgütlerine karş1 duygusal bir his geliştirerek örgütü sanki kendilerininmiş gibi algıladıkları ve davrandıkları kurumsal bir yapı üzerinden açıklamıştır. Bu noktadan sonra da psikolojik sahiplenme kavramı, bireyin bir nesneyi yasal veya resmi sahipliği gerekli olmadan da kendisine ait hissetmesi olarak ifade edilmiştir. Dolayısıyla "psikolojik sahiplik", herhangi yasal bir dayanağı olmadan da bireyin tamamen kişisel hislerine dayanarak zihninde oluşturduğu bir sahiplenme perspektifini yansıtmaktadır.

Yasal sahiplenmenin yokluğunda dahi ortaya çıkabilecek mülkiyet duygularını ifade ettiği için (Mayhew ve Diğ., 2007, s. 477-478) psikolojik sahiplenme önce psikoloji ve sonrasında da işletme akademisyenleri tarafindan büyük ilgi görmüştür. Psikolojik sahiplenmenin en önemli noktasını maddi veya maddi olmayan bir varlığa/nesneye sahip olma ve psikolojik olarak bağlanma hissi oluşturmaktadır. Pierce, Kostova ve Dirks (2001, 2003), psikolojik sahiplenme için üç temel yol belirlemiştir: Hedefi kontrol etme, hedefi yakından tanıma ve kendini hedefe adama. Diğer bir deyişle, bir nesneye karşı psikolojik sahiplenme duyguları geliştirilirken, bireyler o nesneye sahip olmak ve onu kontrol etmek için temel bir motivasyon gösterme eğiliminde olurlar, nesneyle belirli bir düzeyde yakınlık ve aşinalık hissine kapılırlar ve de nesneye belirgin miktarda enerji ve kaynak tahsisinde bulunurlar (Lee ve Chen, 2011, s. 277). İlk olarak hedefi kontrol etme, belirli bir nesnenin kullanımlarından istifade etme ve onları kontrol etme anlamına gelmektedir (Pierce, Kostova ve Dirks, 2003, s. 92). Diğer bir ifadeyle bireyler bir nesneye karşı daha fazla kontrol sergilediklerinde, o nesneye karşı sahiplenme duyguları daha da artmaktadır (Lee ve Suh, 2015, s. 383). İkinci olarak hedefi yakından tanıma, bireylerin bir şeyle sık sık karşılaşmaları ve ona aşina olup o şey sanki kendilerininmiş gibi hissetmeleri anlamına gelmektedir (Pierce, Kostova ve Dirks, 2003, s. 92). Lee ve Suh (2015, s. 383), bireylerin hedef nesneyle aktif temaslarının veya karşılaşmalarının o nesneyle psikolojik bağların oluşmasına sebep olduğunu göstermiştir. Diğer bir deyişle, bir birey sahiplenmek için hedeflenen nesneyle ilgili ek bilgi edindikçe aralarındaki bağ daha da yakın hale gelmektedir. Üçüncü olarak kendini hedefe adama ise bireyin enerjisini, zamanını, çabasını ve dikkatini o nesneye yönlendirmesi ve odaklanması anlamına gelmektedir (Pierce, Kostova ve Dirks, 2003, s. 93). Yani bir nesneye karş1 geliştirilen sahiplenme duygusu bireyin kendini o nesneye adamasıyla ortaya çıkabilmektedir (Zhao, Chen and Wang, 2016, s. 961).

Yasal sahiplenmede, kazanılan haklar yasal sistemde belirtilerek ve koruma altına alınarak öncelikle toplum tarafından tanınmaktayken; psikolojik sahiplenmede ise bunun tersi olarak öncelikle bu hissi taşıyan birey tarafından tanınma gerçekleşmektedir. Dolayısıyla, psikolojik sahiplenmeyle birlikte ilişkilendirilen haklar birey tarafından ortaya konmaktadır. Psikolojik sahiplenme, birçok araştırmacının da belirttiği gibi yasal sahiplenme olmasa da var olabilmektedir. Öyle ki, bireyler yasal 
olarak bir nesneye/eşyaya (otomobil, ev gibi) sahip olabilmekte ama asla o eşyayı kendilerininmiş gibi sahiplenmeyebilmektedirler ("hiçbir zaman bana aitmiş gibi gelmiyor"). $\mathrm{Bu}$ koşullar altında birey nesneyi/eşyayı "kendininmiş" olarak görmemektedir çünkü nesne/eşyanın sembolik özelliklerinde kendisine ait kişisel bir anlam bulamamaktadır ki, bu da bir şeyi "kendinin/kendine ait" olarak tanımlamak için gerekli bir önkoşuldur. Benzer şekilde yasal ve psikolojik sahiplenmeyle ilişkilendirilen sorumluluklar da farklılık göstermektedir. Yasal sahiplenmeyle birlikte gelen sorumluluklar genellikle yasal sistemin bir uzantısıyken psikolojik sahiplenmeyle ilişkilendirilenler ise bireyin kendisinden, kendini sorumlu hissetmesinden ve sahip olmadıkları şeyleri "kendininmiş/kendine aitmiş" gibi addettiği için gösterdiği eylemlerden kaynaklanmaktadır (Pierce, Kostova ve Dirks, 2003, s. 87). Ancak şu da unutulmamalıdır ki yasal sahiplenme, psikolojik sahiplenmenin ortaya çıkmasını kolaylaştırabilmekte hatta hızlandırabilmektedir. Çünkü yasal sahiplenme, bireylerin psikolojik sahiplenmeye vesile olan üç yolu denemesine olanak sağlamaktadır. Yasal sahiplenme, bireye kendi isteği doğrultusunda az ya da çok hedefteki nesneyi kontrol etme veya değiştirme hakkı, hedefteki nesneyi yakından tanıma ve keşfetme imkânı ve kendini o nesneye adama firsatı sunmaktadır (Pierce, Kostova ve Dirks, 2003, s. 96). Bu nedenle de psikolojik sahiplenmenin oluşumunda, kullanıcıların görüş ve beklentilerinin Mercedes marka otomobillerin tasarım kararlarında dikkate alındığı ve kullanıcıların Mercedes otomobilleri üzerinde kontrol sağlayabildiği düşünülmektedir. Bu bağlamda aşağıdaki hipotezi oluşturmak olanaklı hale gelmektedir.

H1: Algılanan kontrol, Mercedes marka otomobil kullanıcısının psikolojik sahipliğini olumlu yönde etkilemektedir.

\subsection{Maksimum Fiyatı Ödeme İstekliliği}

Belirli bir miktarda metaya, müşterilerin ödemek istediği maksimum fiyat olarak tanımlanan ödeme istekliliği, en üst fiyat düzeyi bağlamında değerlendirilmektedir (Wertenbroich ve Skiera, 2002 aktaran Canarslan, 2017, s. 100). Belk (1988), bir nesne sahiplenildiğinde o nesneye karşı daha fazla ilgi, dikkat ve enerjinin gösterildiğine işaret etmiştir. Öyle ki; örgütlerde çalışanların işletmeye karşı psikolojik sahiplenme hissi taşıması durumunda, davranışsal olarak katkıda bulunmak için proaktif oldukları ve işletmelerine faydalı olmak için daha fazla zaman ve enerji harcadıkları görülmektedir (Dyne ve Pierce, 2004, s. 445). Bireylerin sahiplik ve sorumluluk duygusu yüklendikçe davranışlarında değişiklik olacağından hareket edilerek, tüketicilerin bir ürün/markayı tercih ederken alternatiflerine kıyasla psikolojik olarak bağlılık geliştirdiği ürüne gönüllü ve istemli bir şekilde daha fazla ödeme isteği içerisinde bulunabileceğinden hareketle, aşağıdaki hipotezi oluşturmak olanaklı hale gelmiştir.

H2: Mercedes marka otomobil kullanıcısının maksimum fiyatı ödeme istekliliğinin, algllanan kontrol ile psikolojik sahiplenme ilişkisi üzerinde düzenleyicilik etkisi bulunmaktadır.

Kavramsal çerçeveden ve alan yazındaki ampirik çalışmalardan hareketle oluşturulan hipotezler kapsamında, araştırma modelinin şematik gösterimi Şekil 1'de sunulmaktadir: 


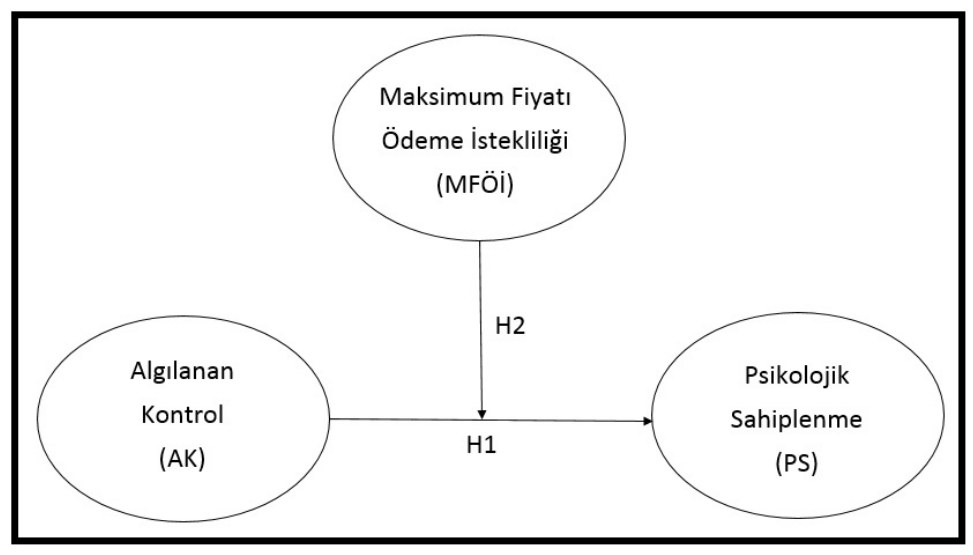

Şekil 1. Araştırmanın Kavramsal Modeli

\section{Araştırmanın Yöntemi}

Tüketicilerin Mercedes markası üzerinde algıladığı kontrolün (AK), markanın kendininmiş gibi hissedilmesini ifade eden psikolojik sahiplenme (PS) üzerindeki etkisini ve bu etkide tüketicilerde oluşacak maksimum fiyatı ödeme istekliliğinin (MFÖİ) düzenleyici rolünü belirlemeye yönelik olan araştırmada; anket çalışmasıyla toplanan verilerin, kuramsal bilgiye bağlı olarak geliştirilmiş olan model ile desteklenip desteklenmediği ortaya konulmuştur. Bu kapsamda sırasıyla örnekleme süreci ve veri toplama yöntemi, anket formunun oluşturulması ve araştırmada kullanılan ölçekler ile verilerin analiz yöntemi detaylı olarak açıklanmıştır.

\section{1. Örnekleme Süreci ve Veri Toplama Yöntemi}

Araştırmanın ana kütlesini Türkiye'de hâlihazırda Mercedes marka otomobil kullananlar oluşturmaktadır. Araştırma kapsamında otomobil markalarından hangisinin seçileceğine karar verebilmek için iki ayrı odak grup çalışması yapılmıştır. Amaçlı ve kartopu örnekleme tekniği kullanılarak odak gruba davet edilen katılımcıların her birini farklı otomobil markalarını kullanan kişiler oluşturmuş ve her iki grupta da birbirinden farklı 10'ar katılımcı bulunmuştur. Otomotiv Distribütörleri Derneği'nin 2017 OcakAralık Perakende Satışlar Pazar Raporundan ulaşılan yerli ve ithal toplam otomobil markası satış rakamlarına göre gruplara katılacak bireyler belirlenmiştir. İlk grupta ilgili dönemde sırasıyla ilk onda yer alan otomobil markalarının (Renault, Volkswagen, Fiat, Hyundai, Opel, Dacia, Toyota, Ford, Nissan, Peugeot) kullanıcılarıyla görüşme yapılırken; ikinci odak grupta da sırasıyla satış rakamlarına göre ikinci onda yer alan otomobil markalarının (Honda, Mercedes, Skoda, Audi, BMW, Seat, Citroen, Kia, Volvo, Suzuki) kullanıcılarıyla görüşülmüsstür. Görüşmeler sonucunda elde edilen veriler, alanında yetkin iki pazarlama akademisyeninden de destek alınarak analiz edilmiştir. Çalışmada kullanılacak marka olarak Mercedes seçilmiştir. Otomobil markaları arasında Mercedes kullanıcısının, diğer kullanıcılarla kıyaslandığında açık ara, kullandığı otomobil markasını sahiplenerek markaya karşı aidiyet geliştirdiği algısındaki eğilim, görüş, tutum ve davranışlarından çapraz ve çok yönlü olarak tespit edilmiştir. Diğerlerine kıyasla Mercedes markası kullanıcısı için kullandığı Mercedes'in, bir otomobil markasından daha fazlasını ifade ettiği ve kullanımının tutku olarak görüldüğü, çoğunlukla başka bir aracı beğenmediği ve gelecekte de Mercedes’ten başka bir aracı tercih etmeyeceği bilgisi de psikolojik sahiplenmeye yönelik söz konusu çalışmada otomobil markası olarak Mercedes'in seçimini kuvvetlendirmiştir. Dolayısıyla psikolojik sahipliğe ilişkin yapılan bir araştırmada Mercedes marka otomobilleri kullanan tüketicilerin ana kütle için uygun olduğu düşünülmüştür. Bu 
kapsamda Mercedes marka otomobil kullanıcıları, cevaplayıcı olarak araştırmaya dâhil edilmiştir. Veriler, internet üzerinden çevrimiçi anket yoluyla 29.01.2018 - 16.05.2018 tarihleri arasında toplanmıştır.

Cevaplayıcıların belirlenmesinde örneğe seçilecek bireylerden sadece ulaşılabilir olanların örnek kapsamına dâhil edilmesini içeren kolayda örnekleme yönteminin araştırmada kullanılması tercih edilmiştir. Bu kapsamda örnek grubunun büyüklüğünün belirlenmesinde, çalışmanın niteliği de göz önüne alındığında $n=\pi(1-\pi) /(e / Z)^{2}$ formülü kullanılarak $\% 5$ hata payı ve $\% 95$ güven aralığında ulaşılması gerekli alt sınırın 384 olduğu tespit edilmiştir (Kurtuluş, 2010, s. 67). 19.02.2018 tarihinde 50 geçerli anket üzerinden öntest yapılmış ve soruların anlaşılır olması ve herhangi bir düzeltmeye ihtiyaç göstermemesi nedeniyle aynı anket formuyla çalışmanın bütün verileri toplanmıştır. Toplanan veriler içerisinde eksik ve hatalı olanlar elimine edildikten sonra kullanılabilir 402 adet Mercedes marka otomobil kullanıcısının cevapladığı nihai anket ile araştırmanın hipotezleri test edilmiştir.

\subsection{Anket Formunun Oluşturulması ve Kullanılan Ölçekler}

Üç bölüm olarak tasarlanan anket formunun ilk bölümünde, cevaplayıcıların hâlihazırda Mercedes marka otomobil kullanıp kullanmadığı sorulmuş ve kullanmayanlar için anket sonlandırılmıştır. İkinci bölümde, cevaplayıcıların Mercedes marka otomobil tercihlerini ve sosyo-demografik özelliklerini belirlemeye yönelik ifadelere yer verilmiştir. Anketin son bölümü olan üçüncü bölümde de çalışma kapsamında test edilen değişkenler olan algilanan kontrolü, maksimum fiyatı ödeme istekliliğini ve psikolojik sahiplenmeyi Mercedes marka otomobil kullanıc1ları üzerinden ölçmeye yönelik geçerliği ve güvenilirliği test edilmiş ölçek ifadelerine yer verilmiştir. Araştırmada kullanılan ölçeklerin hepsi daha önceden yapılmış çalışmaların geçerliliği ve güvenilirliği test edilmiş olan mevcut ölçekleri olup, bu ölçekler alan yazının derinlemesine incelenmesi sonucunda alınıp çalışmaya adapte edilmiştir. Ölçeklerin geçerliliği tercüme-yeniden tercüme, uzman panel ve pilot uygulama yolu izlenerek test edilmiş ve ölçek ifadeleri 5'li Likert tipi ölçekle [(1)Hiç Katılmıyorum...(5)Tam Katılıyorum)] cevaplayıcılara sorulmuştur.

Araştırmada kullanılan ölçeklere ilişkin bilgiler aşağıda verilmektedir:

Algılanan Kontrol Ölçeği: Bireylerin hedefte bulunan nesneler üzerindeki kontrolünü ölçmek amacıyla Agarwal ve Karahanna (2000, s. 693) tarafindan geliştirilmiş bir ölçektir. Ölçek, bireylerin çevrelerindeki nesneler üzerinde doğrudan veya dolaylı etkilerinin kendilerini tesirli hissetmesinden ve çevrelerini kontrol etmesinden kaynaklanan durumu ölçmeyi amaçlayan 3 soru ve tek boyuttan oluşmaktadır. Ölçeğin Mercedes marka otomobillere uyarlanması ve Türkçe geçerlemesi tarafımızdan ve alanında yetkin araştırmacılar tarafından yapılarak; ölçek öncelikle pilot sonrasında da asıl örneklem üzerinde uygulanmıştır.

Ölçeğin yapı geçerliğini test etmek amacıyla Temel Bileşenler Analizi ve Varimaks eksen döndürmesi tekniği kullanılarak Keşfedici Faktör Analizi (KFA) uygulanmıştır. 3 maddelik algılanan kontrol ölçeğinin tek faktörlü bir yapıda olduğu, dolayısıyla verilerin ölçeğin tek faktörlü yapısına uyum sağladığı belirlenmiştir. Analiz sonucunda, faktörlerin toplam varyansın \%79,443'ün açıkladığı ve maddelerin faktör yüklerinin sırasıyla 0,935, 0,934 ve 0,798 değerlerini aldığı tespit edilmiştir. Bartlett Küresellik Testinin anlamlı olması $\left[\mathrm{x}^{2}(3)=775,996, \mathrm{p}<0,001\right]$ maddeler arasındaki korelasyon ilişkilerinin faktör analizi için uygun olduğuna işaret ederken; en alt sınır değer 0,60 olarak kabul edilen Kaiser-Meyer-Olkin (KMO) değeri $(0,668)$ de 
örneklemin büyüklüğünün faktör analizi için yeterli olduğunu göstermektedir (Gürbüz ve Şahin, 2016, s. 311). Ölçekte yer alan ifadelerin iç tutarlılık güvenilirliğini belirlemek amaciyla hesaplanan Cronbach Alpha $(\alpha)$ katsayısı da 0,870 olarak hesaplanmıştır.

Maksimum Fiyatı Ödeme İstekliliği Ölçeği: Müşterilerin bir mal veya hizmete sahip olmak için ödemek istediği en üst düzeydeki fiyat seviyesini ölçmek üzere Zhao, Chen ve Wang (2016, s. 970) tarafından geliştirilen ölçek kullanılmıştır. Geçerliliği çeşitli araştırmalarla ortaya konulan bu ölçeğin; Mercedes'in fiyatları biraz artmış olsa ve yeni ürünleri yüksek fiyatlı bir şekilde satışa sunulsa bile ve diğer alternatif markaların fiyatları biraz düşse bile her halukarda Mercedes müşterisi olarak kalınacağının ifade edildiği 3 maddeden ve tek boyuttan oluştuğu görülmektedir. $\mathrm{Bu}$ noktadan hareketle, ölçeğin uyarlaması ve Türkçe geçerlemesi tarafımızdan ve alanında yetkin araştırmacılar tarafından yapılarak; ölçek öncelikle pilot sonrasında da asıl örneklem üzerinde uygulanmıştır.

Ölçeğin yapısal geçerliğini tespit etmek amacıyla Temel Bileşenler Analizi ve Varimaks eksen döndürmesi tekniği kullanılarak KFA uygulanmıştır. KFA neticesinde KMO örneklem yeterlilik değerinin 0,735 olduğu ve örneklemin büyüklügünün faktör analizi için yeterli olduğu tespit edilmiştir. Barlett küresellik testinin anlamlı olması $\left[\mathrm{x}^{2}(3)=602,551, \mathrm{p}<0,001\right]$ maddeler arasındaki korelasyon ilişkilerinin faktör analizi için uygun olduğuna işaret etmektedir. 3 maddelik ölçeğin üç faktörlü bir yapıda olduğu ve orijinal yapısına uyum sağladığı, faktörlerin toplam varyansın \%79,531'ini açıkladığı ve maddelerin faktör yüklerinin sirasıyla $0,908,0,890$ ve 0,878 olduğu tespit edilmiştir. Yapılan güvenirlik analizi sonucunda ölçeğin toplam Cronbach Alpha katsayısı da 0,866 olarak bulunmuştur.

Psikolojik Sahiplenme Ölçeği: Herhangi bir yasal sahipliliği olmamasına rağmen bireylerin hedeflerindeki nesneye karşı geliştirdiği kişisel sahipliği ve aidiyeti ölçmek üzere Lee ve Chen (2011, s. 287) tarafından geliştirilen ölçek kullanılmıştır. 4 madde ve tek boyuttan oluşan ölçeğin, Mercedes marka otomobillere uyarlanması ve Türkçe geçerlemesi tarafımızdan ve alanında yetkin araştırmacılar tarafından yapılarak; ölçek öncelikle pilot sonrasında da asıl örneklem üzerinde uygulanmıştır.

Verilerin, Mercedes marka otomobillerin kullanıcılarında oluşacak psikolojik sahipliğe ilişkin ölçeğin tek faktörlü yapısına uyum sağladığı, \%78,004 oranında açıklanan varyans oranına sahip olduğu ve faktör yüklerinin sırasıyla $0,852,0,899$, 0,901 ve 0,879 değerlerini aldığı görülmektedir. KMO sonucunun 0,824 , Bartlett Küresellik Testi sonucunun $\left[\mathrm{x}^{2}(6)=1062,129, \mathrm{p}<0,001\right]$ anlamlı olduğu ve Cronbach Alpha katsayısının da 0,905 olduğu bulgusuna ulaşılmıştır.

\section{Bulgular}

Verilerin analizinde ve değerlendirilmesinde SPSS 24.0 ve AMOS 23.0 programı kullanılmıştır. Araştırma sonucunda elde edilen bulguların değerlendirilmesi amacıyla anketi cevaplayan 402 kişiyle ilgili demografik veriler şu şekildedir: Ankete katılan cevaplayıcılardan erkeklerin oranının kadınlara göre daha fazla olduğu [Erkek: 230 (\% 57,2); Kadın: $172(\% 42,8)]$; medeni durum açısından da evlilerin bekârlardan [Evli: 253 (\% 62,9); Bekâr: 149 (\%37,1)] fazla olduğu söylenebilir. Örneklemin yaş aralığ çeşitlilik göstermekle birlikte Mercedes marka otomobil kullanıcılarının beşte dördü (\% 80,3) 38 yaş ve üzerindedir. Bu oranın \% 30, 1'ini 53 yaş ve üzerindeki, \% 16,4'ünü 4852 yaş aralığındaki, \% 15,4'ünü 43-47 yaş aralığındaki ve \% 18,4'ünü 38-42 yaş aralığındaki bireyler oluşturmaktadır. Nispeten orta yaş ve üzerindeki bir örneklem 
çoğunluğu oluştursa da 33-37 yaş aralığındakilerin oranının da azaımsanamayacak düzeyde $(\% 10,4)$ olduğu görülmektedir. Öte yandan anketi cevaplayan bireylerin aylık kişisel gelirleri, üst gelir ve üst-orta gelir grubuna dâhil olduğunu göstermektedir. Bununla birlikte en son aldıkları derece açısından eğitim düzeylerinin son derece yüksek olduğu [Lisans derecesine sahip olanlar: 272 (\% 67,7); Lisansüstü Dereceye sahip olanlar: 112 (\% 27,9)] ifade edilebilir. Bununla beraber, çalışma durumu açısından da bireylerin sirasıyla özel sektörde ve kamuda üst düzey pozisyonlarda çalıştığ1 ve serbest meslek erbab1 olduğu [Özel sektörde işletme sahibi/üst düzey çalışan: 152 (\% 37,8); Kamu sektöründe üst düzey çallşan: 103 (\% 25,6); Serbest meslek erbabl: $90(\%$ 22,4)] tespitine ulaşımıştır.

Araştırma kapsamında yer alan değişkenlerin normallik dağılımlarını ortaya çıkarmak ve dağılım yapısının anlaşılmasını sağlamak için çarpıklık ve basıklık değerleri kontrol edilmiştir (Gürbüz ve Şahin, 2016, s. 216). Çalışmada test edilen algılanan kontrol, maksimum fiyatı ödeme istekliliği ve psikolojik sahiplenme ölçeklerine ilişkin veri setinin çarpıklık değerlerinin -1,190 ile 0,454 arasında, basıklık değerlerinin de $-0,917$ ile 1,216 arasında olduğu görülmüştür. Araştırma modelindeki değişkenlerin -2 ile +2 arasında olması nedeniyle verinin normal dağılım özelliğini gösterdiği söylenebilir (Shao, 2002 aktaran Başgöze ve Özer, 2012, s. 64).

Ölçeklerin yapısal geçerliliğini ve tek boyutluluğunu test etmek için öncelikle Keşfedici Faktör Analizi (KFA) yapılmıştır. Sonrasında, ölçüm modelini test etmek bağlamında ölçeklerin toplanan veriler ile doğrulandığını göstermek amacıyla da Doğrulayıcı Faktör Analizi (DFA) uygulanmıştır. Tek boyutlulukları KFA ile belirlenen değişkenlerin, DFA ile ölçüm modeli test edilmiştir. Bu kapsamda, tüm ölçüm modelini oluşturan değişkenler DFA ile analize alınmıştır. Araştırma modeli kapsamında 3 örtük değişkeni yordayan 10 gözlenen değişkene ait elde edilen DFA sonuçları ile ölçüm modeline ilişkin uyum iyiliği değerleri Tablo 1'de sunulmaktadır.

Tablo 1. Doğrulayıcı Faktör Analizi Sonuçları (N=402)

\begin{tabular}{|c|c|c|c|c|c|}
\hline $\begin{array}{c}\text { Örtük } \\
\text { Değişkenler }\end{array}$ & $\begin{array}{c}\text { Gözlenen } \\
\text { Değişkenler }\end{array}$ & $\begin{array}{c}\text { Standardize Edilmiş } \\
\text { Parametre Değerleri }(\beta)\end{array}$ & $\begin{array}{l}\text { Standart } \\
\text { Hata }\end{array}$ & $\mathbf{t}$ & $\mathbf{p}$ \\
\hline \multirow[t]{3}{*}{$\mathrm{AK}$} & AK1 & 0,946 & & & \\
\hline & $\mathrm{AK} 2$ & 0,926 & 0,035 & 27,896 & $0,000 * *$ \\
\hline & AK3 & 0,640 & 0,041 & 15,128 & $0,000 * *$ \\
\hline \multirow[t]{3}{*}{ MFÖİ } & MFÖİ1 & 0,865 & & & \\
\hline & MFÖİ2 & 0,836 & 0,063 & 18,609 & $0,000 * *$ \\
\hline & MFÖİ3 & 0,799 & 0,061 & 17,833 & $0,000 * *$ \\
\hline \multirow[t]{4}{*}{$\overline{P S}$} & PS1 & 0,741 & & & \\
\hline & PS2 & 0,822 & 0,051 & 19,904 & $0,000 * *$ \\
\hline & PS3 & 0,892 & 0,064 & 17,453 & $0,000 * *$ \\
\hline & PS4 & 0,865 & 0,065 & 17,057 & $0,000 * *$ \\
\hline
\end{tabular}

*Düzeltme öncesi uyum iyiliği değerleri: $\mathrm{p}<0,001, \mathrm{x}^{2}=120,303$, Serbestlik Derecesi $(\mathrm{sd})=32, \mathrm{x}^{2} / \mathrm{sd}=3,759$, RMSEA $=0,083$, CFI $=0,967$, GFI $=0,943$, AGFI $=0,902$, IFI $=0,968$, TLI $=0,954$.

*Düzeltme sonrası uyum iyiliği değerleri: $p<0,001, x^{2}=92,369$, Serbestlik Derecesi $(\mathrm{sd})=31, \mathrm{x}^{2} / \mathrm{sd}=2,980$, RMSEA $=0,070, \mathrm{CFI}=0,977, \mathrm{GFI}=0,958, \mathrm{AGFI}=0,925, \mathrm{IFI}=0,977, \mathrm{TLI}=0,967$.

$* * \mathrm{p}<0,001$

DFA sonuçları neticesinde, ölçüm modeline ait uyum iyiliği değerlerinin genel olarak literatürdeki kabul edilebilir değerler içerisinde olduğu (Schermelleh-Engel, Moosbrugger ve Müller, 2003, s. 52; Gürbüz ve Şahin, 2016, s. 337, Çokluk, Şekercioğlu ve Büyüköztürk, 2014, s. 271-272), dolayısıyla toplanan verilerin 
araştırmada kullanılan ölçeklerin kuramsal yapısına uyum sağladığı tespit edilmiştir. Ölçüm modeli, örtük değişkenlere ilişkin standardize edilmiş parametre değerleri açısından incelendiğinde de, standardize edilmiş parametre değerlerinin zorunlu koşul olan 0,50 'den ve ideal değer olan 0,70 'den yüksek olduğu ve istatistiksel açıdan anlamlı olduğu (Malhotra, 2010, s. 734; Hair ve Diğ., 2006, s. 777) $(\mathrm{p}<0,001)$ görülmektedir. Bu aşamadan sonra, ölçüm modelinin geçerlilik ve güvenilirlik analizleri yapılmıştır.

Araştırma modeli açısından değerlendirildiğinde; yapı güvenilirliği (Composite Reliability-CR) değerlerinin önerilen 0,70'lik düzeyin üzerinde olması (Malhotra, 2010, s. 734), ölçüm modelinin güvenilirliği sağlaması açısından kabul edilebilir olduğunu göstermektedir. Ölçüm modelinin geçerliliği için ise, değişkenlere ilişkin ifadelerin birbirleriyle ve oluşturdukları faktör ile yüksek düzeyde ilişkili olması (yakınsak geçerlilik) ve değişkenlere ilişkin ifadelerin ait olduğu faktörün; diğer faktörlerle, kendi bulundukları faktörden daha az düzeyde ilişkili olması (ıraksak geçerlilik) gerekmektedir (Yaşlıoğlu, 2017, s. 82). Yakınsak geçerlilik için ölçeklere ilişkin tüm yap1 güvenilirliği değerlerinin ortalama açıklanan varyans (Average Variance ExtractedAVE) değerlerinden büyük olması ve AVE değerlerinin de 0,50'den büyük olması beklenmektedir (Bagozzi ve Yi, 1988, s. 82; Yaşlığlu, 2017, s. 82). Her bir yapıy1 (örtük değişkeni) oluşturan gözlenen değişkenlerin, ortalama açıklanan varyans değerlerinin önerilen sınır değer olan 0,50 'den yüksek olması hasebiyle araştırma kapsamında analiz edilen ölçüm modelinin yakınsak geçerliliğe sahip olduğu ifade edilebilir. Iraksak geçerliliğin test edilmesinde ise örtük değişkenler arasındaki korelasyonların karelerinin (paylaşılan varyans değerlerinin) her bir yapı için ortalama açıklanan varyans değerinden düşük olması koşulunun sağlanması aranmaktadır (Fornell ve Larcker, 1981 aktaran Dölarslan ve Özer, 2014, s. 48; Arıkan ve Telci, 2014, s. 97). Araştırma kapsamında elde edilen değerlere göre ölçüm modelini oluşturan örtük değişkenler arasındaki raksak geçerliliğin sağlandığı da ifade edilebilir. Dolayısıyla ölçüm modelinin güvenilirliğine, yakınsak ve rraksak geçerliliğine ilişkin elde edilen değerler Tablo 2'de sunulmaktadır.

Tablo 2. Ölçüm Modelinin Güvenilirliği, Yakınsak ve Iraksak Geçerliliği (N=402)

\begin{tabular}{ccccc}
\hline & Yapı Güvenilirliği & AK & MFÖ̇ & PS \\
\hline AK & 0,88 & $\mathbf{0 , 7 2}$ & & \\
\hline MFÖ̇ & 0,87 & $0,54\left(0,74^{2}\right)$ & $\mathbf{0 , 7 0}$ & $\mathbf{0 , 6 9}$ \\
\hline PS & 0,90 & $0,56\left(0,75^{2}\right)$ & $0,41\left(0,64^{2}\right)$ & \\
\hline * Diyagonal sütunda yer alan değerler yapıların Ortalama Açılkanana Varyans (AVE) değerleridir. Diğer değerler \\
$\begin{array}{l}\text { ise değişkenler arasındaki korelasyonların karesinin hesaplanması ile elde edilen paylaşllan varyans değerlerini } \\
\text { göstermektedir. } \\
* * \text { p }<0,001\end{array}$
\end{tabular}

Araştırma sonucunda elde edilen verilere SPSS programında analizler yapılmış bu kapsamda Mercedes marka otomobil kullanıcılarının algıladıkları kontrole, maksimum fiyatı ödeme istekliliğine ve Mercedes'e psikolojik sahiplenme göstermelerine yönelik cevaplayıcılardan elde edilen verilerin ortalamalarına, standart sapmalarına ve aralarındaki korelasyonlara bakılmıştır. Bulgular, Tablo 3'te yer almaktadır:

Tablo 3. Değişkenlere Ait Ortalama, Standart Sapma ve Korelasyon Katsayıları (N=402)

\begin{tabular}{lccccc}
\hline Değişkenler & Ort. & S.S. & $\mathbf{1}$ & $\mathbf{2}$ & $\mathbf{3}$ \\
\hline 1. Algılanan Kontrol (AK) & 3,04 & 1,05 & - & & \\
\hline 2. Maksimum Fiyatı Ödeme İstekliliği (MFÖI) & 4,07 & 0,86 & $0,334^{*}$ & - & \\
\hline 3. Psikoljik Sahiplenme (PS) & 2,67 & 1,04 & $0,585^{*}$ & $0,385^{*}$ & - \\
\hline${ }^{*} \mathrm{p}<0,001$ & & & &
\end{tabular}


Tablo 3'te görüldüğü gibi araştırmada yer alan değişkenler arasındaki ilişkiler Çoklu Korelasyon Analizi ile araştırılmıştır. Elde edilen bulgulara göre değişkenler arasında anlamlı ve pozitif yönlü bir ilişki olduğu görülmektedir. Diğer bir ifadeyle, değişkenler birlikte artmakta veya azalmaktadır. Değişkenler arasında var olan ilişkiler de orta kuvvettedir.

Araştırmanın hipotezlerini test etmek amacıyla öncelikle Basit Regresyon Analizi yapılmış ve kurulan regresyon modeliyle Mercedes markasına ilişkin algılanan kontrolün (AK), kullanıcıların Mercedes'e güçlü bir şekilde bağlılığını ifade eden psikolojik sahiplik (PS) üzerindeki etkisi Tablo 4'te incelenmiştir (H1). Bu amaçla yapılan basit regresyon analizi sonucunda algilanan kontrol (AK) ile psikolojik sahiplenme (PS) arasındaki ilişkinin pozitif ve anlamlı olduğu $(\beta=0,585, p<0,001)$ görülmüştür. Öte yandan, tüketicilerinin Mercedes markasına ilişkin geliştirdiği psikolojik sahipliğin üzerindeki varyansın \%34'ünün algilanan kontrol tarafından açıklandığı bulgusuna da ulaşılmıştır. Bu bulgu doğrultusunda, araştırmanın H1 hipotezi kabul edilmiştir. Dolayısıyla tüketicilerin Mercedes markasına ilişkin etkisinin/kontrolünün, markayı sahiplenmelerini olumlu yönde etkilediği sonucuna ulaşılmaktadır.

Tablo 4. Algılanan Kontrolün Psikolojik Sahiplenme Üzerindeki Etkisinin Araştırılmasına Yönelik Basit Regresyon Analizi Sonuçları (N=402)

\begin{tabular}{|c|c|c|c|c|c|c|}
\hline Hipotez & Değişkenler & $\beta$ & $\mathbf{t}$ & $\mathbf{p}$ & Tolerans & VIF \\
\hline $\mathrm{H} 1$ & $\mathrm{AK} \rightarrow \mathrm{PS}$ & 0,585 & 14,434 & $0,000 *$ & 1,000 & 1,000 \\
\hline
\end{tabular}

Tüketicilerin Mercedes markası üzerinde algıladığı kontrol (AK) ile marka ile geliştirdiği psikolojik sahiplenme (PS) ilişkisinde, maksimum fiyatı ödeme istekliliğinin (MFÖİ) düzenleyici bir rolünün olup olmadığını test etmek için Hiyerarşik Regresyon Analizi uygulanmıştır. Düzenleyicilik etkisini sınamak için yapılan Hiyerarşik Regresyon Analizinde; algılanan kontrol (AK) bağımsız değişken, psikolojik sahiplenme (PS) bağımlı değişken ve maksimum fiyatı ödeme istekliliği (MFOİ) de düzenleyici değişken olarak modele dâhil edilmiştir (Tablo 5). Bilindiği gibi düzenleyici değişken, bağımlı değişken ile bağımsız değişken arasındaki ilişkinin yönünü ve/veya şiddetini (gücünü) etkileyen niceliksel ya da niteliksel bir değişkendir (Baron ve Kenny, 1986, s. 1174). Buna göre; maksimum fiyatı ödeme istekliliğinin düzenleyici değişken olabilmesi için bu değişkenin bağımsız değişkenle (algılanan kontrol) olan karşılıklı etkileşiminin, bağımlı değişken (psikolojik sahiplenme) üzerinde istatistiksel olarak anlamlı etkisinin olması gerekmektedir. Bu kapsamda; Gürbüz ve Şahin'in (2016) önerileri doğrultusunda, araştırmanın bağımsız değişkeni ve düzenleyici değişkeni standardize (z score) edilmiştir. Sonrasında standardize edilmiş bağımsız değişkenin ve düzenleyici değişkenin çarpılmasıyla etkileşimsel terim oluşturulmuştur. Daha sonra Hiyerarşik Regresyon Analizi için birinci adımda, standardize edilmiş algılanan kontrol (AK) ve maksimum fiyatı ödeme istekliliği (MFOİ) değişkenleri, ikinci adımda ise algılanan kontrolün ve maksimum fiyatı ödeme istekliliğinin çarpımsal sonucu olan etkileşimsel terim (AK x MFOİ) analize dâhil edilmiştir. Düzenleyici değişskene ilişkin analizlerin yorumlarının yapılmasında da beta değeri $(\beta)$ yerine, düzeltilmemiş beta 
değeri (B) rapor edilerek yorumlama yapılmıştır (Aiken ve West, 1991 aktaran Gürbüz ve Bekmezci, 2012, s. 202).

Tablo 5. Maksimum Fiyatı Ödeme İstekliliğinin Düzenleyici Rolüne İlişkin Hiyerarşik Regresyon Analizi Sonuçları $(\mathbf{N}=402)$

\begin{tabular}{|c|c|c|c|c|}
\hline \multirow{2}{*}{ Değişkenler } & \multicolumn{2}{|c|}{ Model 1} & \multicolumn{2}{|c|}{ Model 2} \\
\hline & B & SH & B & SH \\
\hline Alg1lanan Kontrol (AK) & $0,533 *$ & 0,043 & $0,526^{*}$ & 0,043 \\
\hline \multirow{2}{*}{$\begin{array}{l}\text { Maksimum Fiyatı Ödeme İstekliliği (MFÖİ) } \\
\text { AK x MFÖİ }\end{array}$} & $0,222 *$ & 0,043 & \multirow{2}{*}{$\begin{array}{l}0,260 * \\
0,129 *\end{array}$} & 0,044 \\
\hline & & & & 0,037 \\
\hline $\mathrm{R}$ & \multicolumn{2}{|c|}{0,619} & \multicolumn{2}{|c|}{0,634} \\
\hline $\mathrm{R}^{2}$ & \multicolumn{2}{|c|}{0,383} & \multicolumn{2}{|c|}{0,401} \\
\hline Düzeltilmiş $\mathrm{R}^{2}$ & \multicolumn{2}{|c|}{0,380} & \multicolumn{2}{|c|}{0,397} \\
\hline$\Delta \mathrm{R}^{2}$ & \multicolumn{2}{|c|}{0,383} & \multicolumn{2}{|c|}{0,018} \\
\hline
\end{tabular}

Bağımlı Değişken: Psikolojik Sahiplenme (PS)

$* p<0,001$

Maksimum fiyatı ödeme istekliliğinin düzenleyicilik rolüne ilişkin Hiyerarşik Regresyon Analizi sonuçları birinci modelde, algılanan kontrol ile maksimum fiyatı ödeme istekliliği değişkenlerinin regresyon modeline anlamlı katkı yaptıklarını göstermektedir $[\mathrm{F}(2,399)=123,880, \mathrm{p}<0,001]$. Düzeltilmiş $\mathrm{R}^{2}$ değeri 0,380'dir. Bu sonuç, Mercedes marka otomobillere yönelik kullanıcılarda gelişen sahiplenme hissindeki \%38 oranındaki varyansın Mercedes otomobilleri üzerinde sağlayabildikleri kontrol ile maksimum fiyatı ödeme istekliliği değişkenleri tarafından açıklandığını göstermektedir. İkinci modelde, etkileşimsel terimin regresyona girilmesi psikolojik sahiplenme üzerinde \%2'lik ilave varyansı açıklamış ve $\mathrm{R}^{2}$ deki bu değişim anlamlı bulunmuştur $[\mathrm{F}(3,398)=12,190, \mathrm{p}<0,001]$. Bütün değişkenler regresyona girildiğinde algılanan kontrolün $(B=0,526, p<0,001)$ ve maksimum fiyatı ödeme istekliliğinin $(B=0,260$, $\mathrm{p}<0,001)$ psikolojik sahiplenme üzerinde anlamlı etkisi olduğu bulunmuştur. Ayrıca, algılanan kontrol ile maksimum fiyatı ödeme istekliliğinin psikolojik sahiplenme üzerinde anlamlı bir etkileşimsel etkisinin olduğu görülmüştür $(B=0,129, p<0,001)$. Bu bulgu doğrultusunda, araştırmanın H2 hipotezi destek bulmuştur. Diğer bir ifadeyle, algılanan kontrol ile psikolojik sahiplenme arasındaki ilişkinin kullanıcıların Mercedes marka otomobil için maksimum fiyatı ödeme istekliliğine sahip olması tarafından biçimlendiği (moderator) anlaşılmaktadır. Düzenleyici etkiyi yorumlayabilmek için düzenleyici değişkenin ortalama değerinden bir standart sapma eksi ve artı değerlere göre regresyon doğrularının incelenmesi gerekmektedir (Jaccard ve Turrisi, 2003). Düzenleyici etki grafiği (Şekil 2) incelendiğinde algılanan kontrolün psikolojik sahiplenme üzerindeki etkisinin maksimum fiyatı ödeme istekliliğinin yüksek olduğu durumda arttığ1; düşük olduğu durumda ise bu ilişkinin çok fazla etkilenmediği görülmektedir. Sonuç olarak maksimum fiyatı ödeme istekliliği daha fazla olan kullanıcıların algılanan kontrolü arttıkça psikolojik olarak sahiplenmesinin de arttı̆̆ ifade edilebilir. 


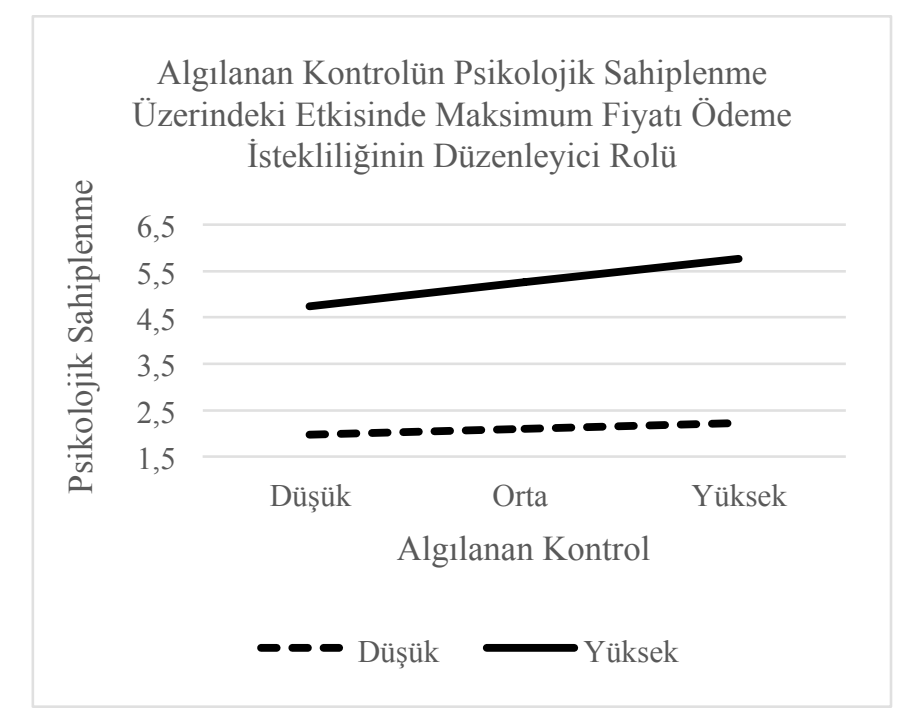

Şekil 2. Algılanan Kontrol ile Psikolojik Sahiplenme İlişkisinde Maksimum Fiyatı Ödeme İstekliliğinin Düzenleyici Etkisi

Öte yandan hiyerarşik regresyon modeli içinde yer alan bağımsız değişkenler arasında çoklu doğrusallık olup olmadığını tespit etmek için değişkenlerin VIF ve Tolerans değerlerine bakılmıştır. Elde edilen Tolerans değerinin 0,2'den büyük ve VIF değerinin de 10'dan küçük olduğu görülmektedir (Gürbüz ve Şahin, 2016, s. 273). Bu bağlamda, çoklu doğrusallık (bağıntı) sorunu olmadığı da ifade edilebilir.

\section{Tartışma ve Sonuç}

$\mathrm{Bu}$ çalışma, psikolojik sahiplenmenin tüketici davranışı bağlamında ele alınmasıyla akademik yazına önemli katkılar sağlamaktadır. Türkiye'de Mercedes marka otomobil kullanıcıları üzerinde ampirik bir araştırma yapılmış; algılanan kontrolün Mercedes kullanıcılarının psikolojik sahipliğine etkisi ve bu etkide maksimum fiyatı ödeme istekliliğinin düzenleyici rolü araştırılmıştır. $\mathrm{Bu}$ kapsamda değişkenler arasındaki etkiler hiyerarşik regresyon analizi ile çözümlenerek; algılanan kontrol ile psikolojik sahiplik ilişkisine yönelik çeşitli bulgulara ulaşılmıştır.

Analiz sonuçları incelendiğinde, algılanan kontrolün psikolojik sahiplenme ile ilişskili olduğu ve psikolojik sahiplenmeyi pozitif ve anlamlı olarak artırdı̆̆ belirlenmiştir. Kullanıcıların görüş ve beklentilerinin, Mercedes marka otomobillerin tasarım kararlarında dikkate alınmasının ve Mercedes otomobilleri üzerinde kontrol sağlayabilmesinin, psikolojik bağın oluşmasına etki eden önemli bir unsur olabileceği ortaya konulmaktadır. Bu bulgunun benzer araştırmalar ile de uyumlu olduğu görülmektedir (Pierce, Kostova ve Dirks (2001, 2003); Zhao, Chen and Wang, 2016, s. 967; Lee ve Chen, 2011, s. 292; Uçar, 2016, s. 52). Algılanan kontrolün, nesne üzerinde kontrol sağlanabilmesini esas alması nedeniyle, kullanıcıların Mercedes marka otomobillere yönelik geliştirilecek psikolojik sahiplenmeyi olumlu ve yüksek düzeyde etkilemesi beklenilmiştir. Maksimum fiyatı ödeme istekliliği de tüketicilerin davranışlarını etkileyen bir değişken olarak değerlendirilmektedir. $\mathrm{Bu}$ noktadan hareketle, algılanan kontrolün psikolojik sahiplenmeye olan etkisinde maksimum fiyatı ödeme istekliliğinin düzenleyici rolü araştırılmıştır. $\mathrm{Bu}$ kapsamda elde edilen bulgulardan hareketle, algılanan kontrolün psikolojik sahiplenmeye etkisinde maksimum fiyatı ödeme istekliliğinin düzenleyici rolü olduğu belirlenmiştir. 
Düzenleyiciliği araştırılan maksimum fiyatı ödeme istekliliğinin yüksek olduğu kullanıcılarda, düşük olanlardan daha kuvvetli bir algılanan kontrol-psikolojik sahiplenme ilişkisi beklenmiş ve analiz sonuçları da beklentiye uygun sonucun elde edildiğini ortaya koymuştur. Dolayısıyla Mercedes marka otomobil kullanmak için daha fazla düzeyde ödeme isteği içerisinde olan kullanıcılarda, algılanan kontrol ile psikolojik sahiplenme arasındaki ilişkinin daha kuvvetli olduğu tespitine ulaşılmaktadır.

Sonuç olarak, kullanıcıların Mercedes otomobilleri üzerinde kontrol sağlayabilmesinin Mercedes marka otomobillere ilişkin psikolojik sahiplenme geliştirmesinde önemli etkisi olduğu ortaya konulmuştur. Günümüzde işletmenin sunduğu bir değer önerisine yönelik tüketicilerin yasal sahipliğin ötesinde psikolojik olarak sahiplik geliştirmesinin, maksimum fiyatı ödeme istekliliği değişkeni vasıtasıyla daha etkin bir şekilde gerçekleştirilebileceğinin tespitine araştırma sonucunda ulaşılmıştır. Bu kapsamda sektör uygulayıcılarına, işletmeler tarafından sunulan ürünler üzerinde tüketicilerin kontrol sağlayabilmesi durumunda, tüketiciler tarafından ilgili ürüne ilişkin psikolojik olarak hissedilen duygusal ve bilişsel sahiplenmenin artacağ bununla birlikte tüketicilerin ilgili ürüne ilişkin maksimum fiyatı ödeme istekliliğinin yüksek olması durumunda da psikolojik sahiplenmenin daha kuvvetli bir şekilde ortaya çıkabileceği önerisinde bulunulabilir.

Araştırma kapsamında her ne kadar Mercedes kullanıcılarının tercih ettikleri otomobil markalarına yönelik psikolojik sahiplikleri üzerinde etki gösteren değişkenler anlaşılmaya çalışılsa da maddi olmayan varlıklar üzerinde de araştırmaların yapılması markaya karşı psikolojik sahiplenmenin daha iyi anlaşılması için fikir verecektir. Bireylerde duygusal hislere dayanarak ortaya çıkan sahipliği açıklayan psikolojik bağların, tüketicilerin davranışlarını etkileyeceği ve değişikliğe yol açacağı muhakkaktır. Araştırma, söz konusu duygusal bağl1lığa sebep olabilecek öncülleri anlamaya odaklanarak alan yazına katkı sağlayacak bir çeşitlilikle durumu ele almıştır. Öte yandan gelecek araştırmalarda, psikolojik sahipliğin davranışsal manada yaratacağı çıktılara ilişkin çalışmaların yapılmasının alan yazına katkı sağlayacağı düşünülmektedir.

\section{KAYNAKÇA}

Agarwal, R., Karahanna, E., (2000). "Time flies when you're having fun: Cognitive absorption and beliefs about information technology usage", MIS Quarterly, Vol. 24, No. 4, 665-694.

Alkaya, B. D., Devrani, T. K., (2018). "Dokunma ihtiyacı ve yazılı bilginin psikolojik sahiplik üzerindeki etkisi”, Pazarlama ve Pazarlama Araştırmaları Dergisi, Cilt. 11, Say1. 22, 205-232.

Arıkan, E., Telci, E. E., (2014). "Marka özgünlüğü ve boyutlarının müşteri tutum ve satın alma davranışı üzerindeki etkileri”, Pazarlama ve Pazarlama Araştırmaları Dergisi, Cilt. 7, Sayı. 14, 87-106.

Asatryan, V. S., Oh, H., (2008). "Psychological ownership theory: An exploratory application in the restaurant industry", Journal of Hospitality \& Tourism Research, Vol. 32, No. 3, 363-386.

Bagozzi, R. P., Yi, Y., (1988). "On the evaluation of structural equation models", Journal of the Academy of Marketing Science, Vol. 16, No. 1, 74-94. 
Baron, R. M., Kenny, D. A., (1986). "The moderator-mediator variable distinction in social psychological research: Conceptual, strategic and statistical considerations", Journal of Personality and Social Psychology, Vol. 51, No. 6, 1173-1182.

Başgöze, P., Özer, L., (2012). “Gender effect on brand credibility and purchase relation: Does BC vary among different brands", International Journal of Arts and Commerce, Vol. 1, No. 5, 58-69.

Belk, R. W., (1988). "Possessions and the extended self". Journal of Consumer Research, Vol. 15, No: 2, 139-168.

Belk, R. W., (1989). "Extended self and extending paradigmatic perspective”, Journal of Consumer Research, Vol: 16, No: 1, 129-132.

Canarslan, N. Ö., (2017). "Kitlesel bireyselleştirilmiş ürünler için ödeme istekliliği: Kadın müşteriler üzerine bir araştırma", Tüketici ve Tüketim Araştırmaları Dergisi, Cilt. 9, Say1. 1, 95-115.

Çokluk, Ö., Şekercioğlu, G., Büyüköztürk Ş., (2014). Sosyal Bilimler İçin Çok Değişkenli İstatistik: SPSS ve LISREL Uygulamaları, 3. Bask1, Pegem Akademi, Ankara.

Dölarslan, E. Ş., Özer, A., (2014). "Hizmet kalitesi, tatmin ve güvenin daha fazla ödeme eğilimi üzerindeki etkileri”, Anadolu Üniversitesi Sosyal Bilimler Dergisi, Cilt. 14, Say1. 1, 31-58.

Dyne, L. V., Pierce, J. L., (2004). "Psychological ownership and feelings of possession: Three field studies predicting employee attitudes and organizational citizenship behavior", Journal of Organizational Behavior, Vol. 25, 439-459.

Fuchs, C., Prandelli, E., Schreier, M., (2010). "The psychological effects of empowerment strategies on consumers' product demand", Journal of Marketing, Vol. 74, No. 1, 65-79.

Gürbüz, S., Bekmezci, M., (2012). “İnsan kaynakları yönetimi uygulamalarının bilgi işçilerinin işten ayrılma niyetine etkisinde duygusal bağlılığın aracılık ve düzenleyicilik rolü”, İstanbul Üniversitesi İşletme Fakültesi Dergisi, Cilt. 41, Say1. 2, 189-213.

Gürbüz, S., Şahin, F., (2016). Sosyal Bilimlerde Araştırma Yöntemleri: FelsefeYöntem-Analiz, 3. Baskı, Seçkin Yayıncılık, Ankara.

Hair, J.F., Black, W.C., Babin, B.J., Anderson, R.E., Tatham, R.L., (2006). Multivariate Data Analysis, 6th Edition, Pearson Prentice Hall, New Jersey.

Hulland, J., Thompson, S. A., Smith, K. M., (2015). "Exploring uncharted waters: Use of psychological ownership theory in marketing", Journal of Marketing Theory and Practice, Vol. 23, No. 2, 140-147.

Jaccard, J., Turrisi, R., (2003). Interaction Effects in Multiple Regression, 2nd Edition, Sage Publications Inc., Thousand Oaks: California.

Jussila, I., Tarkiainen, A., Sarstedt, M., Hair, J. F., (2015). "Individual psychological ownership: Concepts, evidence, and implications for research in marketing", Journal of Marketing Theory and Practice, Vol. 23, No. 2, 121-139. 
Karahanna, E., Xu, S. X., Zhang, N. A., (2015). "Psychological ownership motivation and use of social media", Journal of Marketing Theory and Practice, Vol. 23, No. 2, 185-207.

Kurtuluş, K., (2010). Araştırma Yöntemleri, Türkmen Kitabevi, İstanbul.

Lee, J., Suh, A., (2015). "How do virtual community members develop psychological ownership and what are the effects of psychological ownership in virtual communities?", Computers in Human Behavior, Vol. 45, 382-391.

Lee, Y., Chen, A. N., (2011). "Usability design and psychological ownership of a virtual World", Journal of Management Information Systems, Vol. 28, No. 3, 269-307.

Liu, J., Wang, H., Hui, C., Lee, C., (2012). "Psychological ownership: How having control matters", Journal of Management Studies, Vol. 49, No. 5, 869-895.

Malhotra, N. K., (2010). Marketing Research: An Applied Orientation, 6th Edition, Pearson Education Inc., New Jersey.

Mayhew, M. G., Ashkanasy, N. M., Bramble, T., Gardner, J., (2007). "A study of the antecedents and consequences of pscyhological ownership in organizational settings", Journal of Social Pscyhology, Vol. 147, No: 5, 477-500.

Pierce, J. L., Kostova, T., Dirks, K. T., (2001). "Toward a theory of psychological ownership in organizations", Academy of Management Review, Vol. 26, No. 2, 298-310.

Pierce, J. L., Kostova, T., Dirks, K. T., (2003). "The state of psychological ownership: Integrating and extending a century of research", Review of General Psychology, Vol. 7, No. 1, 84-107.

Schermelleh-Engel, K., Moosbrugger, H., Müller, H., (2003). "Evaluating the fit of structural equation models: Tests of significance and descriptive goodness-of-fit measures", Methods of Psychological Research Online, Vol. 8, No. 2, 23-74.

Uçar, Z., (2016). "Kontrol algısı-psikolojik sahiplenme ilişkisi üzerinde algılanan aşırı vasıflılığın düzenleyicilik etkisi”, International Journal of Applied Business and Management Studies, Vol. 1, No. 1, 40-58.

Yaşlıoğlu, M. M., (2017). "Sosyal bilimlerde faktör analizi ve geçerlilik: Keşfedici ve doğrulayıcı faktör analizlerinin kullanılması”, İstanbul Üniversitesi İşletme Fakültesi Dergisi, Cilt. 46, Sayı. Özel Sayı, 74-85.

Zhao, Q., Chen, C. D., Wang, J. L., (2016). "The effects of psychological ownership and TAM on social media loyalty: An integrated model", Telematics and Informatics, Vol. 33, No. 4, 959-972. 


\section{EK: Ölçekler}

\begin{tabular}{|c|c|c|c|}
\hline Faktör & İfadeler & Kisaltmalar & Ölçek Tipi \\
\hline \multirow{3}{*}{$\begin{array}{l}\text { Algilanan } \\
\text { Kontrol } \\
(\mathrm{AK})\end{array}$} & $\begin{array}{l}\text { Mercedes markasının, görüşlerimi/beklentilerimi r sorarak } \\
\text { otomobillerinin tasarımına aktif olarak katılmama imkân sağladığını } \\
\text { düşünüyorum. }\end{array}$ & AK1 & \multirow{3}{*}{$\begin{array}{c}\text { 1= Kesinlikle Kat1lmiyorum } \\
5=\text { Kesinlikle Katıliyorum }\end{array}$} \\
\hline & $\begin{array}{l}\text { Fikirlerimin Mercedes otomobillerinin tasarım kararlarında dikkate } \\
\text { alındığını hissediyorum. }\end{array}$ & AK2 & \\
\hline & $\begin{array}{l}\text { Mercedes markasını kullandığım sürece kontrolün bende olduğunu } \\
\text { düşünüyorum. }\end{array}$ & AK3 & \\
\hline \multirow{3}{*}{$\begin{array}{l}\text { Maksimum } \\
\text { Fiyatı } \\
\text { Ödeme } \\
\text { İstekliliği } \\
\text { (MFÖİ) }\end{array}$} & $\begin{array}{l}\text { Otomobil satın almadan önce fiyatlarında az da bir artış gerçekleşse, } \\
\text { Mercedes müşterisi olarak kalırım. }\end{array}$ & MFÖİ1 & \multirow{3}{*}{$\begin{array}{c}\text { 1= Kesinlikle Katılmiyorum } \\
5=\text { Kesinlikle Kat1liyorum }\end{array}$} \\
\hline & $\begin{array}{l}\text { Mercedes'e eklenen yeni fiyatlı ürünleri satın almaya devam etmek } \\
\text { için Mercedes müşterisi olarak kalırım. }\end{array}$ & MFÖİ2 & \\
\hline & $\begin{array}{l}\text { Alternatif otomobillerin fiyatları biraz daha düşük olsa bile, otomobil } \\
\text { satın almak için Mercedes müşserisi olarak kalırım. }\end{array}$ & MFÖİ3 & \\
\hline \multirow{4}{*}{$\begin{array}{l}\text { Psikolojik } \\
\text { Sahiplenme } \\
\quad \text { (PS) }\end{array}$} & Mercedes benim markamdır. & PS1 & \multirow{4}{*}{$\begin{array}{c}\text { 1= Kesinlikle Kat1lmiyorum } \\
5=\text { Kesinlikle Kat1liyorum }\end{array}$} \\
\hline & $\begin{array}{l}\text { Mercedes markasına karşı çok yüksek düzeyde kişisel sahiplenme } \\
\text { hissediyorum. }\end{array}$ & PS2 & \\
\hline & Mercedes markasının sanki bana ait olduğunu hissediyorum. & PS3 & \\
\hline & Mercedes'e hiç ısınamadım, bana ait hissetmiyorum.* & PS4 & \\
\hline
\end{tabular}

* Ters madde 


\title{
Moderating Role of Willingness to Pay More in the Effect of Perceived Control on Psychological Ownership: A Study on Mercedes Brand Automobile Owners
}

\author{
Selma KALYONCUOĞLU \\ Ankara Hacı Bayram Veli University \\ Faculty of Economics and Administrative Sciences \\ Ankara, Turkey \\ orcid.org/0000-0003-4745-7836 \\ selmakalyoncuoglu@gmail.com
}

\section{Introduction}

Individuals' feelings of psychologically strong bond to tangible or intangible objects even though they do not have legal ownership of the objects was first put forward as psychological ownership in the related academic literature by Pierce, Kostova and Dirks (2001). People have possessed a variety of objects since the dawn of time and this ownership has been the cornerstone of societies. Considering the psychological dimension of ownership rather than legal ownership enables individuals to feel and perceive the target object as their own beyond legal rights related to the object which are acquired by individuals. Therefore, "the feeling of possessing the object as theirs" emerges in psychological ownership even though it may not emerge in legal ownership. With this regard, this concept was considered to be effective in individuals' behaviours and attitudes and especially studied on organization employees (Hulland, Thompson ve Smith, 2015; Jussila ve Diğ., 2015; Karahanna, Xu ve Zhang, 2015; Zhao, Chen and Wang, 2016; Alkaya ve Devrani, 2018). In time, researchers started to tackle the concept of psychological ownership in marketing literature (Hulland, Thompson and Smith, 2015; Jussila et al., 2015; Karahanna et al., 2015; Zhao et al., 2016). In this study, psychological bond developed by consumers towards Mercedes brand was investigated following personal observations of the researcher herself in a focus group study.

The main aim of this study is to tackle the effect of perceived control of consumers of Mercedes brand on psychological ownership, and to investigate the role of willingness to pay more in this effect. One of the main contributions of the study to the literature is investigating the effect of perceived control on psychological ownership developed towards the brand by consumers who have legal ownership as well as investigating moderating role of willingness to pay more in this effect. The study is composed of three parts. In the first part, concepts related to the study were defined. In the second part, analyses of the hypotheses were conducted to determine the effect of perceived control on psychological ownership and the mediating role of willingness to pay more in this effect, and then the findings were presented. In the last part, results of the study were discussed and recommendations for future studies were provided.

\section{Design and Method}

This study aimed to investigate the effect of customers' perceived control over Mercedes brand on psychological ownership which refers to feeling as if the brand belonged to them, and to analyse moderating role of customers' willingness to pay more in this effect. Data gathered through a survey were tested with a model developed on the 
basis of theoretical background to reveal whether the model was supported with the data. In this section, sampling procedure, data collection method, survey form development, scales used in the study and data analysis method were described in detail, respectively.

In the first part of the survey which was composed of three parts, respondents were asked whether they used Mercedes brand automobile, if not, the survey was finalized for them. In the second part, items were presented in order to gather information about respondents' Mercedes brand automobile preferences and their sociodemographic characteristics. The last part of the survey included items related to variables of the study namely perceived control, willingness to pay more, psychological ownership which measured the effect of the variables on Mercedes brand automobile owners. Validity and reliability of items presented in the scales were already tested and verified in previous studies, and these scales were adapted after a thorough review of the related literature. Validity of the scales were tested through translation-back translation procedure, expert panel and a pilot study, and scale items were presented to respondents in a five point Likert scale [(1) Strongly disagree...(5) Strongly agree]. Perceived control scale composed of 3 items and a single factor which was developed by Agarwal and Karahanna (2000, p. 693) to measure individuals' control over targeted objects was used in the study. Willingness to pay more scale which was developed by Zhao, Chen and Wang (2016, p. 970) was utilized to measure the highest level of price which customers are willing to pay for a good or service. This scale also consisted of 3 items and a single dimension. Psychological ownership scale composed of 4 items and a single factor which was developed by de Lee and Chen (2011, p. 287) was used to measure individual ownership and belonging for targeted objects even though there is no legal ownership.

The sample of the study was composed of Mercedes brand automobile owners in Turkey. Two separate focus group studies were conducted in order to decide which brand of automobile would be chosen within the scope of the study. By using judgmental and snowball sampling methods, each of invited participants to the focus group was owner of different automobile brands and both groups included 10 different participants. Automobile owners were reached thanks to 2017 January-December Retail Sales Market Report of Automotive Distributors' Association and individuals who would be included in the groups were determined according to total sale numbers of domestic and exported automobile brands. In the first group, interviews were carried out with owners of top ten automobile brands (Renault, Volkswagen, Fiat, Hyundai, Opel, Dacia, Toyota, Ford, Nissan, and Peugeot), in the second focus group study, interviews were carried out with owners of next top ten automobile brands (Honda, Mercedes, Skoda, Audi, BMW, Seat, Citroen, Kia, Volvo, Suzuki). Following the interviews, collected data were analysed with the support of two competent academicians in the field of marketing. As a result of the analysis of two focus group studies, Mercedes was chosen as the brand to be used in this study. As a result of cross and multidimensional analysis of participants' tendency in perception, opinions, attitudes and behaviours, it was found that among owners of all other automobile brands, Mercedes owners developed by far larger sense of belonging to the brand and showed a high degree of ownership compared to other automobile owners. It was revealed that the brand Mercedes meant more than just an automobile brand for Mercedes owners compared to others, and Mercedes owners considered it a passion to drive their automobiles. It was also found that most of the time Mercedes owners did not like other automobiles and 
would not prefer to have another brand of car other than Mercedes in the future. Such psychological ownership factors confirmed the reason why the brand Mercedes was chosen for this study. Therefore, it was believed that in a study on psychological ownership, it would be appropriate to have Mercedes owners as the sample of the study. Within this scope, Mercedes brand automobile owners were included in the study as respondents. Data were collected via an online survey between the dates of 29.01.2018 and 16.05.2018. After the elimination of data which had missing and incorrect data points, a total of 402 final surveys were used to test the hypotheses of the study.

\section{Findings}

SPSS 24.0 and AMOS 23.0 software programmes were used in the analysis and evaluation of the data. Exploratory Factor Analysis (EFA) was carried out in order to test structural validity and unidirectionality of the scales. The fact that Barlett's Test of Sphericity was significant for each variable $(\mathrm{p}<0.001)$ showed that the study was appropriate for factor analysis. It was found that KMO (Kaiser-Meyer-Olkin) values of perceived control, willingness to pay more and psychological ownership variables were $0.668,0.735$ and 0.824 , respectively. This shows that this sample size meets the necessary condition for factor analysis (KMO values equal or above 0.60) (Gürbüz and Şahin, 2016, p. 311). Abovementioned variables had Cronbach's Alpha coefficient values of $0.870,0.866$ and 0.905 , respectively, showing that each scale was highly reliable (Kayiş, 2006, p. 405).

After Exploratory Factor Analysis, with the aim of testing measurement model, Confirmatory Factor Analysis (CFA) was applied in order to show that collected data confirm with the scales. Three main variables, namely "perceived control, willingness to pay more and psychological ownership" each of which included three items and a single dimension were used in the study. Considering the variables within the scope of CFA, factorial structure and composite reliability of three dimensions (perceived control, willingness to pay more and psychological ownership) constituting the measurement model were tested and collected data showed that scales complied with theoretical background. Following the confirmation of the measurement model, correlation analysis was conducted to show the relation between the scales thus the hypotheses of the study were tested.

First of all, Simple Regression Analysis was carried out to test the hypotheses of the study, and with the regression model, the effect of perceived control (PC) over brand of Mercedes on psychological ownership (PO) referring to Mercedes owners' strong commitment to the brand was investigated (H1). The result of simple regression analysis showed that there was a positive and significant relation between perceived control and psychological ownership $(\beta=0.585, p<0.001)$. It was revealed that perceived control explained $34 \%$ of the variance of psychological ownership developed by Mercedes customers towards the brand. Based on this finding, H1 hypothesis was supported. Therefore, it was concluded that customers' effect/control on Mercedes brand had a positive effect on showing ownership of the brand.

In order to test moderating effect, perceived control was added to Hierarchical Regression Analysis as an independent variable, psychological ownership was added as a dependent variable, and willingness to pay more was included to the model as a moderating variable. In the first model, results of Hierarchical Regression Analysis of moderating role of willingness to pay more showed that variables of perceived control and willingness to pay more had significant contributions to the regression model 
$[\mathrm{F}(2,399)=123.880, \mathrm{p}<0.001]$. Adjusted $\mathrm{R}^{2}$ value was 0.380 . This result showed that variables of Mercedes owners' control over the brand and willingness to pay more explained $38 \%$ of variance in feeling of ownership developed by Mercedes brand automobile owners. In the second model, interaction effect was included in the regression and this explained additional $2 \%$ of variance and this change in $\mathrm{R}^{2}$ was found to be significant $[\mathrm{F}(3,398)=12.190, \mathrm{p}<0.001]$. When all variables were included in the regression model, it was found that perceived control $(B=0.526, p<0.001)$ and willingness to pay more $(B=0.260, p<0.001)$ had significant effects on psychological ownership. Furthermore, the results revealed that perceived control and willingness to pay more had significant interaction effect on psychological ownership $(B=0.129$, $\mathrm{p}<0.001)$. In line with this finding, $\mathrm{H} 2$ hypothesis of the study was supported. In other words, it is understood that the relation between perceived control and psychological ownership is moderated by Mercedes brand automobile owners' willingness to pay more. It is seen that the effect of perceived control on psychological ownership increases when the willingness to pay more is high, and if this willingness is low, this relation is not affected much. As a whole, it can be stated that as the perceived control of customers who are more willing to pay more increases, their psychological ownership level also increases. It was found that tolerance value was above 0.2 and VIF value was below 10 (Gürbüz and Şahin, 2016, p. 273). In this case, it can be said that there is no multicollinearity problem.

\section{Conclusion and Discussion}

This study is believed to greatly contribute to the literature by tackling psychological ownership within the framework of consumer behaviour. An empirical study was conducted on Mercedes brand automobile owners in Turkey and the study investigated the effect of perceived control on psychological ownership of Mercedes owners as well as the moderating role of willingness to pay more in this effect. Accordingly, effects between the variables were analysed with hierarchical regression analysis and a number of findings have been found regarding the relation between perceived control and psychological ownership.

Based on analysis results, it was concluded that there was a significant relation between perceived control and psychological ownership and perceived control had a positive effect on increase in psychological ownership. It is seen that this finding is consistent with similar studies in the literature (Pierce, Kostova and Dirks (2001, 2003); Zhao, Chen and Wang, 2016, p. 967; Lee and Chen, 2011, p. 292; Uçar, 2016, p. 52). It was expected that perceived control would have positive and high level effect on psychological ownership to be developed by automobile owners towards Mercedes brand because perceived control primarily relies on having control over the object. Willingness to pay more is also considered to be a variable which affects consumer behaviour. Therefore, this study investigated moderating role of willingness to pay more in the effect of perceived control on psychological ownership. The findings showed that willingness to pay more had a moderating role in the effect of perceived control on psychological ownership. It has been expected that there would be stronger relation between perceived control and psychological ownership in individuals who were more willing to pay more compared to those who were less willing to pay more, and analysis results revealed that the findings were in line with this expectation. Therefore, it has been concluded that the relation between perceived control and psychological ownership was stronger in individuals who were more willing to pay more to have a Mercedes brand automobile. 